DOI 10.32900/2312-8402-2019-122-4-17

УДК 639.211

\title{
OXIDATIVELY MODIFIED PROTEINS LEVEL IN THE MUSCLE TISSUE OF THE RAINBOW TROUT (ONCORHYNCHUS MYKISS WALBAUM) AS A BIOMARKER OF ANTIOXIDANT PROPERTIES OF LEAF EXTRACTS OF CAMELLIA JAPONICA L. CULTIVARS (THEACEAE D. DON)
}

\author{
Buyun L., Doctor of Biological Sciences \\ Kharchenko I., Ph.D. \\ Maryniuk M., Post-graduate student \\ M. M. Gryshko National Botanic Garden, National Academy of Science of \\ Ukraine, Kyiv, Ukraine \\ Tkachenko H., Doctor of Biological Sciences \\ Osadowski Z., Doctor of Biological Sciences \\ Institute of Biology and Environmental Protection, Pomeranian University in Słupsk, \\ Poland
}

In this study, we investigated the antioxidative activity of plant extracts by the measurement of aldehydic and ketonic derivatives of oxidatively modified proteins. In our study, Camellia japonica L. 'Kramer's Supreme', Camellia japonica 'C. M. Wilson', Camellia japonica 'La Pace', Camellia japonica 'Benikarako', Camellia japonica 'Fanny Bolis' were protectively effective extracts caused the decrease of protein oxidative damage in the muscle tissue of rainbow trout. The leaves of various Camellia japonica cultivars, cultivated under glasshouse conditions, were sampled at M. M. Gryshko National Botanical Garden (NBG), National Academy of Sciences of Ukraine. Freshly collected leaves were washed, weighed, crushed, and homogenized in $100 \mathrm{mM}$ phosphate buffer ( $\mathrm{pH}$ 7.2) (in proportion 1:19, w/w) at room temperature. The extracts were then filtered and investigated. Clinically healthy rainbow trout with a mean body mass of 80-120 g were used in the experiments. The muscle tissue samples were homogenized in ice-cold buffer (100 mM Tris-HCl, pH 7.2) using a glass homogenizer immersed in ice water bath. Homogenates were centrifuged at 3,000 $\mathrm{g}$ for $15 \mathrm{~min}$ at $4^{\circ} \mathrm{C}$. The supernatant of the muscle tissue was used to incubate with extracts of various cultivars of $C$. japonica (in a ratio 19:1) at room temperature. The positive control group (trout muscle tissue) was incubated with $100 \mathrm{mM}$ Tris-HCl buffer (pH 7.2) (in a ratio 19:1). The incubation time was 2 hours. When muscle tissue was incubated with leaf extracts of various $C$. japonica cultivars, the aldehydic derivatives level was ranged to the value of the control group. Among the six plant extracts, C. japonica 'La Pace' exhibited the highest inhibitory effect (the decrease of ketonic derivatives was $28.2 \%$, $p<0.05$ compared to the control group). The level of ketonic derivatives of oxidatively modified proteins in the sample with C. japonica 'Mrs. Lyman Clarke' was increased by $2.8 \%$ ( $p>0.05)$ compared to controls. The least level of ketonic derivatives is attributed to C. japonica 'La Pace' extract. Therefore, Therefore, Camellia japonica may be used as an antioxidant agent in aquaculture as it can be easily obtained and is not expensive. Furthermore, the use of such plant products as antioxidants and immunostimulants in aquaculture systems may also have environmental value because of their biodegradability.

Keywords: rainbow trout (Oncorhynchus mykiss Walbaum), muscle tissue, Camellia japonica L., cultivars, oxidatively modified proteins. 
Nutritional studies showed the key role of some nutrients on fish antioxidant and immune systems as crucial for maintaining animal health and its ability to fight diseases $[2,27]$. In fish, evidence supporting the essentiality of nutrients for maintaining normal immune functions is on the increase. The implicated nutrients include proteins, essential fatty acids, polysaccharides, the antioxidant vitamins $\mathrm{C}$ and $\mathrm{E}$, and some of the trace minerals like $\mathrm{Zn}$ and Se [18]. Algae, herbs, plant extracts rich in polyphenols, green tea extracts and essential oils are also used in aquaculture for immune enhancement and improved disease resistance $[2,27]$. Assessing antioxidant modulation in relation to nutrition is very important. The development of prooxidative and antioxidant responses is an important step for a better understanding of nutritional modulation of the antioxidant response. The techniques for assessment of oxidative stress biomarkers provide more possibilities for the investigation of the fish response, especially lipid peroxidation and oxidatively modified proteins in the study in vitro [14-16].

The oxidative modification of proteins by reactive species, especially reactive oxygen species, is formed through a large number of physiological and nonphysiological reactions. An increase in the rate of their production or a decrease in their rate of scavenging will increase the oxidative modification of cellular molecules, including proteins [34].

For the most part, oxidatively modified proteins are not repaired and must be removed by proteolytic degradation, a process that normally proceeds very efficiently, from microorganisms to mammals. In eukaryotes, removal is usually carried out by the proteasome, which selectively degrades oxidatively modified proteins, whether they are damaged by reactive oxygen species or specifically oxidized by cellular regulatory processes [21]. Accumulation of modified proteins disrupts cellular function either by loss of catalytic and structural integrity or by interruption of regulatory pathways [34].

Increased levels of oxidatively modified proteins (i.e., protein carbonyls) have been observed in age-related diseases, such as neurodegenerative diseases (Alzheimer's, Parkinson's, and Huntington's diseases), cataractogenesis, systemic amyloidosis, muscular dystrophy, progeria, Werner's syndrome, rheumatoid arthritis, and respiratory distress syndrome $[4,7,24]$.

Camellia genus belongs to the Theaceae family, found in southern and eastern Asia, from the Himalayas east to Japan and Indonesia. Green tea (Camellia sinensis (L.) Kuntze) has received much attention as a beverage worldwide during the last few decades due to its various beneficial effects on human health, including different types of cancer, heart disease, and liver disease, etc. [3, 6]. Studies reveal that green tea possesses diverse pharmacological properties to lower the incidence of metabolic syndromes, such as obesity, type II diabetes, and cardiovascular risk factors [6]. Long-term consumption of tea catechins could be beneficial against high-fat diet-induced obesity and type II diabetes and could reduce the risk of coronary disease [6]. Green tea was also reported as useful against HIV strains [10].

Camellia japonica is the most well-known species of the genus Camellia. C. japonica (Japanese name of «tsubaki») has traditionally been a popular tree as both a garden ornamental plant and as the source of oil material and folk medicine in Japan. An edible oil known as 'tsubaki oil' is obtained from the seed [9, 19, 38]. Dried flowers are used as a vegetable cooked or mixed with gelatinous rice to make a Japanese food called 'mochi' [9] or used as a flower tea [19]. The leaves serve as a substitute for tea and tobacco $[9,17,35]$. It was initially found in Korea, Japan, China, and Taiwan between altitudes of 300-1100 m [13] but actually it is disseminated throughout the world [33]. In fact, in the north of Spain (Galicia), around 2.5 million Camellia plants (the majority of $C$. japonica) are produced and exported to other European coun- 
tries [30, 33]. These plants present vast phenotypic differences, more than 32,000 known cultivars [39], and possess a great economical value due to its beautiful flowers [30]. The study of its genetic structure revealed that these plants maintain high levels of genetic diversity and a high evolutionary potential which makes them less susceptible to environmental stresses [28]. This could explain with these species are also well adapted in many other countries [33].

The leaf extract of $C$. japonica exhibited the most potent effect on degranulation in antigen-stimulated rodent and human mast cells of 100 Korean plants screened [20]. Aqueous extract from $C$. japonica leaf has antioxidant and neuronal cell protective effects. It including phenolics may be useful in the natural antioxidant substance and reduce the risk of neurodegenerative disease such as Alzheimer's disease [12]. Among eight Camellia species, $C$. sasanqua showed potent anticancer activities in prostate cancer PC 3 cells. In addition to catechins, the major component, eugenyl $\beta$-primeveroside was detected in $C$. sasanqua [40]. The Camellia spp. the extract possesses a wide range of pharmacological activities including anti-inflammatory, anti-cancer, anti-microbial, and antioxidant activities [1, 26, 29, 41].

Although pharmacological activities of extracts from various parts of Camellia species were well investigated, studies regarding its protective effects against oxidative damage in the muscle tissue of the rainbow trout (Oncorhynchus mykiss Walbaum) have not yet been undertaken. Therefore we focused on investigating the in vitro antioxidant effect of leaf extracts of $C$. japonica cultivars. Consequently, the aim of this study was to evaluate the oxidative damage of proteins (aldehydic and ketonic derivatives as biomarkers) in the muscle tissue of rainbow trout after incubation with extracts obtained from leaves of various Camellia japonica cultivars.

Materials and methodology. Collection of Plant Material. The leaves of $\mathrm{Ca}$ mellia japonica 'Kramer's Supreme', C. japonica 'C.M.Wilson', C. japonica 'La Pace', C. japonica 'Mrs. Lyman Clarke', C. japonica 'Benikarako', C. japonica L. 'Fanny Bolis' cultivated under glasshouse conditions, were sampled at M. M. Gryshko National Botanical Garden (Kyiv, Ukraine).

Preparation of Plant Extracts. Freshly collected leaves were washed, weighed, crushed, and homogenized in $100 \mathrm{mM}$ sterile phosphate buffer saline solution ( $\mathrm{pH}$ 7.2) (in proportion 1:19, w/w) at room temperature. The extracts were then filtered and investigated. All extracts were stored at $-20^{\circ} \mathrm{C}$ until use.

Experimental fish. Clinically healthy rainbow trout with a mean body mass of 80-120 $\mathrm{g}$ were used in the experiments. The experiments were performed in water at $14.5 \pm 0.5^{\circ} \mathrm{C}$ and $\mathrm{pH} 7.2-7.4$. The dissolved oxygen level was about $9 \mathrm{ppm}$ with additional oxygen supply, with a water flow of $25 \mathrm{~L} / \mathrm{min}$, and a photoperiod of $12 \mathrm{~h}$ per day. The same experimental conditions were used during the whole research. The water parameters were maintained under constant surveillance. The fish were held in square tanks (150 fish per tank) and fed commercial pelleted diet.

Collection of muscle tissue samples. The muscle tissue samples were homogenized in ice-cold buffer $(100 \mathrm{mM}$ Tris- $\mathrm{HCl}, \mathrm{pH} 7.2)$ using a glass homogenizer immersed in an ice water bath. Homogenates were centrifuged at 3,000 g for $15 \mathrm{~min}$ at $4^{\circ} \mathrm{C}$. After centrifugation, the supernatant was collected and frozen at $-20^{\circ} \mathrm{C}$ until analyzed. Protein contents were determined with the method described by Bradford (1976) with bovine serum albumin as a standard [5]. Absorbance was recorded at $595 \mathrm{~nm}$. All enzymatic assays were carried out at $22 \pm 0.5{ }^{\circ} \mathrm{C}$ using a Specol 11 spectrophotometer (Carl Zeiss Jena, Germany). The enzymatic reactions were started by adding the tissue supernatant.

Experimental design. The supernatant of the muscle tissue was used to incubate 
with leaf extracts of various cultivars of $C$. japonica (in a ratio of 19:1) at room temperature. The positive control group (trout muscle tissue) was incubated with $100 \mathrm{mM}$ Tris$\mathrm{HCl}$ buffer ( $\mathrm{pH}$ 7.2) (in a ratio of 19:1). The incubation time was 2 hours. Lipid peroxidation biomarker was evaluated in the incubated homogenate (control group and in samples with extracts of various cultivars of $C$. japonica).

The carbonyl derivatives content of protein oxidative modification (OMP) assay. To evaluate the protective effects of the extract against free radical-induced protein damage, a carbonyl derivatives content of protein oxidative modification (OMP) assay based on the spectrophotometric measurement of aldehydic and ketonic derivatives in the samples was performed. The rate of protein oxidative destruction was estimated from the reaction of the resultant carbonyl derivatives of amino acid reaction with 2,4dinitrophenylhydrazine (DNFH) as described by Levine and co-workers (1990) and as modified by Dubinina and co-workers (1995). DNFH was used for determining carbon$\mathrm{yl}$ content in soluble and insoluble proteins. Briefly, $1 \mathrm{~mL}$ of $0.1 \mathrm{M} \mathrm{DNPH}$ (dissolved in $2 \mathrm{M} \mathrm{HCl}$ ) was added to $0.1 \mathrm{~mL}$ of the sample after denaturation of proteins by $20 \%$ trichloroacetic acid (TCA). After addition of the DNPH solution (or $2 \mathrm{M} \mathrm{HCl}$ to the blanks), the tubes were incubated for a period of $1 \mathrm{~h}$ at $37^{\circ} \mathrm{C}$. The tubes were spun in a centrifuge for $20 \mathrm{~min}$ at 3,000 g. After centrifugation, the supernatant was decanted and $1 \mathrm{~mL}$ of ethanol-ethylacetate solution was added to each tube. Following the mechanical disruption of the pellet, the tubes were allowed to stand for $10 \mathrm{~min}$ and then spun again (20 min at 3,000 g). The supernatant was decanted and the pellet washed thrice with ethanol-ethylacetate. After the final wash, the protein was solubilized in $2.5 \mathrm{~mL}$ of $8 \mathrm{M}$ urea solution. To speed up the solubilization process, the samples were incubated in a $90^{\circ} \mathrm{C}$ water bath for $10-15 \mathrm{~min}$. The final solution was centrifuged to remove any insoluble material. The carbonyl content was calculated from the absorbance measurement at $370 \mathrm{~nm}$ and $430 \mathrm{~nm}$, and an absorption coefficient 22,000 $\mathrm{M}^{-1} \cdot \mathrm{cm}^{-1}$. Carbonyl groups (nmol per mg of protein) were determined spectrophotometrically from the difference in absorbance at $370 \mathrm{~nm}$ (aldehyde derivatives, $\mathrm{OMP}_{370}$ ) and $430 \mathrm{~nm}$ (ketonic derivatives, $\left.\mathrm{OMP}_{430}\right)[8,22]$.

Statistical analysis. The mean \pm S.E.M. values were calculated for each group to determine the significance of the intergroup difference. All variables were tested for normal distribution using the Kolmogorov-Smirnov and Lilliefors test ( $p>0.05)$. The significance of differences (significance level, $\mathrm{p}<0.05$ ) was examined using the Kruskal-Wallis test by ranks [42]. All statistical calculation was performed on separate data from each individual with STATISTICA 8.0 software (StatSoft, Krakow, Poland).

Results and discussion. When muscle tissue was incubated with leaf extracts of various $C$. japonica cultivars, the aldehydic derivatives level was ranged to the value of the control group. Moreover, all extracts increase the aldehydic derivatives level in the extracts-treated muscle tissue (from $1.7 \%$ for Camellia japonica 'C.M.Wilson' to $5.4 \%$ for Camellia japonica 'La Pace', respectively), but these differences were not statistically significant (Fig. 1A).

The crude extracts were also analyzed for their antioxidant efficacy by the determination of their inhibitory effect of protein oxidative damage, i.e. ketonic derivatives in the muscle tissue of the rainbow trout. Among the six plant extracts, $C$. japonica 'La Pace' exhibited the highest inhibitory effect (the decrease of ketonic derivatives was $28.2 \%, \mathrm{p}<0.05$ compared to the control group). The C. japonica 'Benikarako', C. japonica L. 'Fanny Bolis', and C. japonica 'Kramer's Supreme', and C. japonica 'C.M.Wilson' exhibited levels of ketonic derivatives (14.44 \pm 0.66$)$, (14.02 \pm 0.97$)$, (13.16 \pm 0.66$),(12.90 \pm 0.63) \mathrm{nmol}$ per mg protein, respectively, compared to value in the control group (14.66 $\pm 0.69 \mathrm{nmol}$ per $\mathrm{mg}$ protein), as shown in Fig. 1B. The level of ke- 
tonic derivatives of oxidatively modified proteins in the sample with $C$. japonica 'Mrs. Lyman Clarke' was increased by $2.8 \%$ ( $>>0.05)$ compared to controls. The least level of ketonic derivatives is attributed to C. japonica 'La Pace' extract (Fig. 1B).

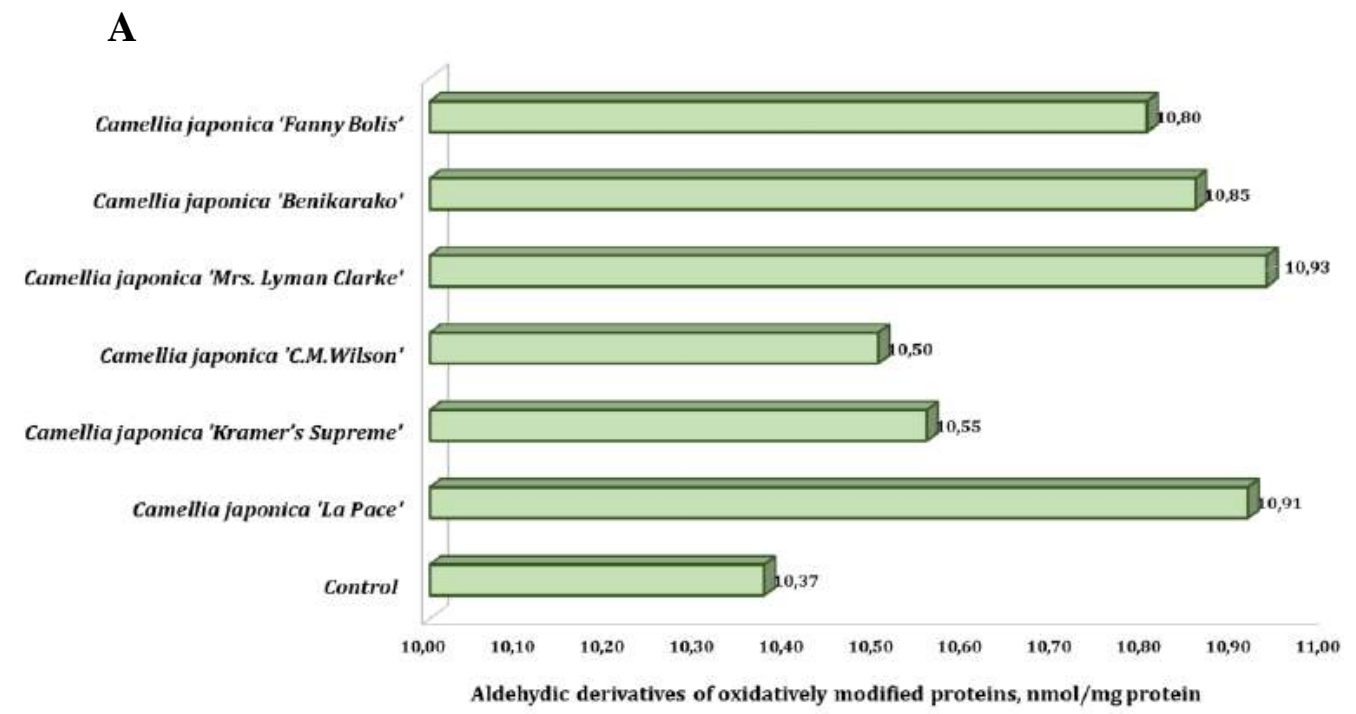

B

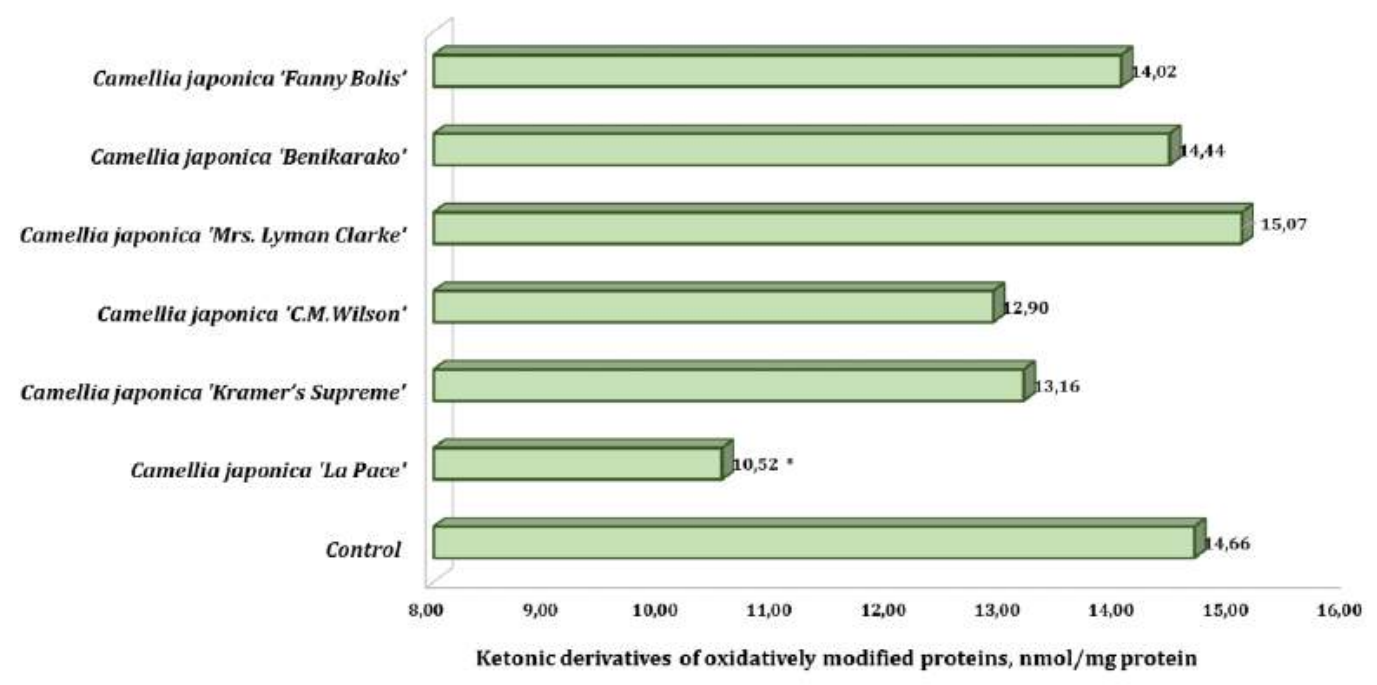

Fig. 1. The aldehydic (A) and ketonic derivatives (B) of oxidatively modified proteins in the muscle tissue of rainbow trout after incubation with extracts from leaves of various Camellia japonica cultivars $(M \pm m, n=6)$.

* changes are statistically significant $(\mathrm{p}<0.05)$ compared to the control group.

In this study, we investigated the antioxidative activity of plant extracts by the measurement of aldehydic and ketonic derivatives of oxidatively modified proteins. In our study, Camellia japonica L. 'Kramer's Supreme', C. japonica 'C.M. Wilson', C. japonica 'La Pace', C. japonica 'Benikarako', C. japonica 'Fanny Bolis' were protectively effective extracts for the decrease of protein oxidative damage in the muscle tissue of rainbow trout.

In a separate study, we tested these extracts for toxic effects on human erythrocytes. $C$. japonica and its cultivars were found to be non-toxic on the concentrations tested for antimicrobial activity (data not shown). Results obtained in our previous study showed that there is a possibility of using extracts derived from leaves of various C. japonica cultivars in intensive aquaculture farms. Leaf extracts of Camellia japonica may 
be used as an antioxidant agent in aquaculture. The lipid peroxidation (2-thiobarbituric acid reactive substances (TBARS) as biomarker) level in the muscle tissue of rainbow trout (Oncorhynchus mykiss Walbaum) after incubation with extracts obtained from leaves of various Camellia japonica cultivars was evaluated in our previous study [14]. Moreover, all extracts (except $C$. japonica 'Benikarako' and 'Fanny Bolis') reduced the TBARS level in the extracts-treated muscle tissue, but these results were nonsignificant. Furthermore, the use of such plant products as antioxidants and immunostimulants in aquaculture systems may also have environmental value because of their biodegradability [14]. The superoxide dismutase (SOD) activity, an antioxidant enzyme, was increased in the muscle tissue after incubation with $C$. japonica 'Kramer's Supreme' extract (by $52 \%, \mathrm{p}=0.004$ ), C. japonica 'C.M. Wilson' (by 88 \%, p=0.001), C. japonica 'Mrs. Lyman Clarke' (by $87.2 \%, \mathrm{p}=0.000$ ), and $C$. japonica 'Fanny Bolis' (by $40.7 \%, \mathrm{p}=0.044$ ) compared to the control group. The SOD activity in the muscle tissue after incubation with Camellia japonica 'La Pace' and Camellia japonica 'Benikarako' was also non-significantly increased by $31.5 \%$ and $27.3 \%(\mathrm{p}<0.05)$, respectively [15]. The results of the investigation revealed quite a high level of total antioxidant capacity (TAC) in samples of muscle tissue incubated with leaf extracts of $C$. japonica 'C.M. Wilson' and C. japonica 'Benikarako' cultivars. The levels of TAC were increased by $41.7 \%$ and $44.8 \%(\mathrm{p}<0.05)$ as compared with a control group of muscle tissue homogenates. Leaf extracts of $C$. japonica 'La Pace' and $C$. japonica 'Kramer's Supreme' cultivars being incubated with muscle tissue have not changed the level of TAC, while the effect of the leaves extracts of C. japonica 'Mrs. Lyman Clarke' and C. japonica 'Fanny Bolis' on the decreasing of TAC level was insignificant ( $>0.05)$. The results of the study suggested the high antioxidant capacity of Camellia cultivars screened give reason to believe that application of these plant extracts signifies a rational curative strategy to prevent and cure various fish diseases involving oxidative stress by increasing the ability of a fish organism to adapt [16]. It is well known that the $\mathrm{Ca}$ mellia japonica leaf exhibits antioxidant activity because of its high content of polyphenolic compounds [25].

The results obtained in the current study can be correlated with the previous publications. The antioxidant role of the green tea (Camellia sinensis) extract (GTE) was examined to remedy the toxic effects of $\left.\left(0.2 \mathrm{mg}^{-1}\right)^{-1}\right)$-nonylphenol(4-NP) in the study of Sayed and Soliman (2018). Biochemical parameters, antioxidant enzymes, liver lipid peroxidation (LPO), DNA fragmentation, and apoptosis, as well as histopathology of the liver of African catfish Clarias gariepinus, were considered. Catfishes were divided into four groups: first group (control), second group $\left(0.2 \mathrm{mg} \cdot 1^{-1}\right.$ of 4-NP), third group $\left(0.2 \mathrm{mg} \cdot 1^{-1}\right.$ of $4-\mathrm{NP}+100 \mathrm{mg} \mathrm{GTE} 1^{-1}$ water $)$, and fourth group $\left(0.2 \mathrm{mg} \cdot \mathrm{l}^{-1}\right.$ of $4-\mathrm{NP}$ +200 $\mathrm{mg} \mathrm{GTE}^{-1}$ water). The results obtained by Sayed and Soliman (2018) showed that significant increments of serum glucose, AST, ALT, total protein, total lipids, cholesterol, G6PDH, and cortisol. Meanwhile, serum acetylcholinesterase, ALP, and LDH were significantly reduced. In addition, antioxidant enzymes (SOD, CAT, GST, and TAC) levels were reduced in 4-NP treated fish compared to control. Also, there were significant increments in hepatic LPO, DNA fragmentation, and apoptotic erythrocytes in 4-NP treated fish compared to control. The liver of 4-NP treated fish showed some histopathological alterations such as vacuolization in hepatocytes, congestion in a central vein, infiltration of mononuclear inflammatory cells, and necrosis as well as depletion of glycogen content of the liver. The addition of green tea extract into the water restored the alterations in most of those biomarkers induced by 4-NP. Sayed and Soliman (2018) concluded that GTE has a protective role against hepatic failure, depletion of antioxidant defense, and genotoxicity induced 4-NP in C. gariepinus [31]. 
The study of Nootash and co-workers (2013) elucidates the efficacy of green tea (Camellia sinensis) on growth performance, immune and antioxidant systems and cytokine gene expression in rainbow trout tissues. Green tea was supplemented at 20, 100, and $500 \mathrm{mg} \mathrm{kg}^{-1}$ diet and fed to fish (average weight: $23.5 \mathrm{~g}$ ) for 35 days. No remarkable changes in growth performance were observed among all test groups. Lower lipid peroxidation product and higher superoxide dismutase activity were noted in fish received the medium dose of green tea. A significant increase in serum bactericidal activity and total protein were recorded in all treatment groups. All doses of green tea upregulated Interleukin-1 $\beta$ transcription in the spleen, while Interleukin- $1 \beta$ mRNA level decreased significantly in the kidney of a low dose of green tea. Interleukin- 6 mRNA level was up-regulated in the spleen of a high dose of green tea and liver of middle and high doses of green tea. High dose and a medium dose of green tea up-regulated the interleukin-8 transcription in the kidney and liver, respectively. Meanwhile, green tea inhibited the production of interleukin-10 in all treatment groups compared with the control group. Medium dose of green tea up-regulated tumor necrosis factor- $\alpha$ transcription in all fish tissues, while high dose and a low dose of green tea enhanced tumor necrosis factor- $\alpha$ mRNA levels in the kidney and spleen, respectively. Although the precise mechanisms responsible for green tea effect on immune-related genes expression remain to be explored more, it might be related to some components such as catechins, flavonols, flavanones, phenolic acids of plant pigments. Polyphenols are a diverse group of naturally occurring compounds with different biological functions. The study of Nootash and co-workers (2013) suggests that green tea, especially at $100 \mathrm{mg} \mathrm{kg}^{-1}$ feed, may effectively enhance the antioxidant system and immune system in rainbow trout [27].

In order to study the immunomodulatory effects of decaffeinated green tea extract on rainbow trout, a study with a 30-day feeding trial was conducted by Sheikhzadeh and co-workers (2011). Commercial diets with graded levels of decaffeinated green tea extract, $20 \mathrm{mg}$ (T1), $100 \mathrm{mg}$ (T2), $500 \mathrm{mg}$ (T3) per kg feed were prepared. 120 rainbow trout $(35 \pm 3 \mathrm{~g})$ were randomly assigned to 4 groups in triplicates and fed one of the 3 experimental diets formulated or a control diet. After feeding trial, 12 fish from each group were sampled for analysis of some immunological parameters. Remaining fish were injected with $0.5 \mathrm{ml}$ of chicken red blood cell (C-RBC) suspension $(2 \%)$ intraperitoneally on days 5 and 15 after feeding trial. Results showed that the inclusion of $20 \mathrm{mg}$ $\mathrm{kg}^{-1}$ green tea (T1) in the fish diet enhanced the serum bactericidal activity against Yersinia ruckeri, while the significant elevation of lysozyme activity was shown in the T2 group. Anti-trypsin activity due to $\alpha 1$-antiprotease was significantly higher in T1 and T2 groups while peroxidase content showed a significant increase in all treatment groups compared to the control group. Hemagglutination antibody titer against C-RBC was significantly higher in fish administered with $100 \mathrm{mg} \mathrm{kg}^{-1}$ green tea (T2). The findings of Sheikhzadeh and co-workers (2011) showed that decaffeinated green tea in lower doses of administration could be optimum to enhance the immunity of rainbow trout [32].

For evaluating the protective effects of green tea in fish received oxidized oil, the study was done by Hasanpour and co-workers (2017). The lipid content of the diet was replaced by oxidized fish oil (OFO) in 0,50 , and $100 \%$. Green tea extract (GTE) was added to the diet in three levels, 0,5 , and $100 \mathrm{mg} / \mathrm{kg}$ giving a total of nine experimental diets. Two hundred and seventy sturgeon hybrid of Sterlet (Huso huso $9 \times$ Acipenser ruthenus ${ }^{\Uparrow}$ ) with an initial weight of $212.6 \pm 0.7 \mathrm{~g}$ after 2 weeks adaptation randomly divided in 27 fiberglass tanks with $700 \mathrm{~L}$ volume. Fish were fed satiated three times daily. After 6 weeks, biometry was done to evaluate growth performance and 
blood samples were taken for biochemical analysis. The result showed that feeding with oxidized oil had no effects on growth. However, in fish fed GTE, growth indices improved slightly. Feeding with OFO reduced serum total cholesterol, triacylglycerol, and low-density lipoprotein, while increased high-density lipoprotein. Dietary GTE moderated the effects of OFO on lipid metabolism. Feeding with the OFO increased activity of serum superoxide dismutase, catalase, glutathione peroxidase, and malondialdehyde contents. In fish received both OFO and GTE, reduced activity of serum antioxidant enzymes and malonic dialdehyde content was recorded in compare to fish fed only OFO. According to the result of the Hasanpour and co-workers (2017) study, it can be argued that feeding of sturgeon hybrid of Sterlet with OFO has negative effects on lipid metabolism and antioxidant status, whereas GTE dosages used in their study have protective effects on fish from the adverse effects of oxidized oil [11].

Long and co-workers (2017) have investigated the effects of the single or combined use of Selenium yeast (SY) and tea polyphenols (TP) as natural antioxidant supplements in fish feed on growth performance and nitrite resistance through determining the changes in serum hormones, hepatic histology and antioxidant responses of Wuchang bream exposed to nitrite. In order to explore the effects of dietary selenium yeast, tea polyphenols and their combination on growth of Wuchang bream (Megalobrama amblycephala) and its resistance to nitrite stress, 360 healthy Wuchang bream with initial body weight of $(55.90 \pm 2.60) \mathrm{g}$ were randomly divided into four groups: a control group fed with basal diet and three treated groups fed with basal diets supplemented with $0.50 \mathrm{mg} / \mathrm{kg}$ selenium yeast, $50 \mathrm{mg} / \mathrm{kg}$ tea polyphenols, and the combination of $0.50 \mathrm{mg} / \mathrm{kg}$ selenium yeast and $50 \mathrm{mg} / \mathrm{kg}$ tea polyphenols, respectively. After $60 \mathrm{~d}$ of feeding, the growth performance of Wuchang bream was measured. Then 25 fish per tank was exposed to nitrite stress of $15.0 \mathrm{mg} / \mathrm{L}$. The serum stress hormones, liver histology, and hepatic antioxidant responses were evaluated before nitrite exposure $(0 \mathrm{~h})$ and at $6,12,24,48$ and $96 \mathrm{~h}$ after exposure. The results showed that before nitrite exposure, compared with the control, the weight gain, specific growth rate, liver total antioxidant capacity, the activities and transcriptional levels of hepatic antioxidant enzymes (superoxide dismutase and glutathione peroxidase) in the selenium yeast and combination groups were significantly increased, while feed conversion rate was decreased significantly, which suggested that the combined use of selenium yeast and tea polyphenols as well as the single selenium yeast supplementation improved growth performance and enhanced antioxidant capacity in fish. After nitrite exposure, compared with the control, liver total antioxidant capacity, as well as the activities and transcription levels of catalase superoxide dismutase and glutathione peroxidase in three treatment groups, were significantly increased in varying degrees whereas serum cortisol contents and liver malonic dialdehyde levels were decreased significantly. By contrast, the combined use of selenium yeast and tea polyphenols was more effective than the single supplementation with selenium yeast or tea polyphenols. Inconsistent with this, alterations of the liver histological structure in three treatment groups were slower and less severe than in the control group after nitrite exposure. In conclusion, a basal diet supplemented with the combination of $0.50 \mathrm{mg} / \mathrm{kg}$ selenium yeast and $50 \mathrm{mg} / \mathrm{kg}$ tea polyphenols could effectively improve growth performance and nitrite resistance in Wuchang bream. Furthermore, the combination use of SY and TP in fish feed have better effects than the single SY supplementation in term of growth performance, antioxidant responses and histological recovery [23].

Thawonsuwan and co-workers (2010) have revealed the potential of Epigallocatechin-3-gallate (EGCG), a very potent antioxidant derived from green tea, as an antioxidant and an immunostimulant for rainbow trout, at least at the inclusion level of 
$32 \mathrm{mg} \cdot \mathrm{kg}^{-1}$ diet. Epigallocatechin-3-gallate was compared with vitamin $\mathrm{E}$ in terms of its effects on antioxidant defense and immune response of rainbow trout, by means of a feeding trial of eight weeks. Two of the experimental diets were supplemented with EGCG at either 20 or $100 \mathrm{mg} \cdot \mathrm{kg}^{-1}$ diet (which contained only $30 \%$ of the intended levels) and the third was provided with $100 \mathrm{mg} \mathrm{kg}^{-1}$ vitamin $\mathrm{E}$ but not EGCG. The control diet was not supplemented with the test components. Observation of tissue levels indicated that the high amount of EGCG helped to increase the availability of the lipidsoluble antioxidant vitamin E. The lower levels of lipid hydroperoxide in the liver of fish fed the higher amount of EGCG suggested that it was an effective antioxidant. Considering the immune indices, EGCG and vitamin E at $100 \mathrm{mg}$ (actual amounts 31.9 and $94.1 \mathrm{mg} \cdot \mathrm{kg}^{-1}$ diet, respectively) had identical capabilities in improving phagocytic activity and controlling hydrogen peroxide production by leucocytes. However, EGCG could possibly be more effective at enhancing serum lysozyme activity and the alternative complement activity. Thus, although not distinctly, EGCG at the higher amount applied in the study has demonstrated its potential as an antioxidant in fish. The low levels of lipid hydroperoxide in the livers of the TH group (high tea fed levels) suggest that EGCG is an effective antioxidant [37].

Although the precise mechanisms responsible for effects of Camellia japonica and its cultivars on protein oxidative damage remain to be explored more, it might be related to some components such as catechins, flavonols, phenolic acids of plant pigments. Polyphenols are a diverse group of naturally occurring compounds with different biological functions. Many polyphenols such as catechins can regulate antioxidant reactions [36, 43].

Conclusions. In conclusion, the present results indicate that using extracts derived from leaves of various Camellia japonica cultivars to incubation with the muscle tissue of rainbow trout leads to a decrease of protein oxidatively damage. To obtain further insights into this important issue, more work should also be performed to evaluate whether the $C$. japonica cultivars' effect on different oxidative stress biomarkers in fish tissues was in a time-course manner. Based on our observations, we hypothesize that Camellia japonica may be used as a supplementary/dietary antioxidant agent in aquaculture for protection against complications arising from oxidative stress as it can be easily obtained and is not expensive. Furthermore, the use of such plant products as antioxidants and immunostimulants in aquaculture systems may also have environmental value because of their biodegradability.

\section{References}

1. Akihisa, T., Yasukawa, K., Kimura, Y., Takase, S., Yamanouchi, S., Tamura, T. (1997). Triterpene alcohols from camellia and sasanqua oils and their antiinflammatory effects. Chem. Pharm. Bull. (Tokyo), 45(12), 2016-2023. DOI: $10.1248 / \mathrm{cpb} .45 .2016$.

2. Amar, E. C., Kiron, V., Satoh, S., Watanabe, T. (2004). Enhancement of innate immunity in rainbow trout (Oncorhynchus mykiss Walbaum) associated with dietary intake of carotenoids from natural products. Fish Shellfish Immunol., 16(4), 527537. DOI: 10.1016/j.fsi.2003.09.004.

3. Bashir, S., Khan, B. M., Babar, M., Andleeb, S., Hafeez, M., Ali, S., Khan, M. F. (2014). Assessment of Bioautography and Spot Screening of TLC of Green Tea (Camellia) Plant Extracts as Antibacterial and Antioxidant Agents. Indian J. Pharm. Sci., 76(4), 364-370. PMCID: PMC4171874.

4. Berlett, B. S., Stadtman, E. R. (1997). Protein oxidation in aging, disease, and oxidative stress. Journal of Biological Chemistry, 272, 20313-20316. 
DOI: $10.1074 /$ jbc.272.33.20313.

5. Bradford, M. M. (1976). A rapid and sensitive method for the quantitation of microgram quantities of protein utilizing the principle of protein-dye binding. Anal. Biochem., 72, 248-254. DOI: 10.1006/abio.1976.9999.

6. Chacko, S. M., Thambi, P. T., Kuttan, R., Nishigaki, I. 2010. Beneficial effects of green tea: a literature review. Chin. Med., 5, 13. DOI: 10.1186/1749-8546-5-13.

7. Dalle-Donne, I., Giustarini, D., Colombo, R., Rossi, R., Milzani, A. (2003). Protein carbonylation in human diseases. Trends in Molecular Medicine, 9(4), 169-176. DOI: 10.1111/j.1582-4934.2006.tb00407.x.

8. Dubinina, E. E., Burmistrov, S. O., Khodov, D. A., Porotov, I. G. (1995). Oxidative modification of human serum proteins. A method of determining it. Voprosy Meditsinskor Khimii, 41, 24-26 (Article in Russian, Abstract in English).

9. Facciola, S. (1990). Cornucopia. A source book of edible plants. Vista: Kampong Publishing, 677 p.

10. Fassina, G., Buffa, A., Benelli, R., Varnier, O. E., Noonan, D. M., Albini, A. (2002). Polyphenolic antioxidant (-)-epigallocatechin-3-gallate from green tea as a candidate anti-HIV agent. AIDS, 16(6), 939-941. DOI: 10.1097/00002030200204120-00020.

11. Hasanpour, S., Salati, A. P., Falahatkar, B., Azarm, H. M. (2017). Effects of dietary green tea (Camellia sinensis L.) supplementation on growth performance, lipid metabolism, and antioxidant status in a sturgeon hybrid of Sterlet (Huso huso $\hat{\delta} \times$ Acipenser ruthenus +) fed oxidized fish oil. Fish Physiol. Biochem., 43(5), 1315-1323. DOI: 10.1007/s10695-017-0374-z.

12. Jeong, C. H., Kim, J. H., Choi, G. N., Kwak, J. H., Kim, D. O., Heo, H. J. (2010). Protective effects of extract with phenolics from camellia (Camellia japonica) leaf against oxidative stress-induced neurotoxicity. Food Sci. Biotechnol., 19(5): 13471353. DOI: 10.1007/s10068-010-0192-x.

13. Kanth, B. K., Lee, K. Y., Lee, G. J. (2014). Antioxidant and radicalscavenging activities of petal extracts of Camellia japonica ecotypes. Hortic. Environ. Biotechnol., 55: 335-341. DOI: 10.1007/s13580-014-0024-7.

14. Kharchenko, I., Maryniuk, M., Buyun, L., Tkachenko, H., PażontkaLipiński, P., Witaszek, M., Osadowski, Z. (2017). Lipid peroxidation level in the muscle tissue of the rainbow trout (Oncorhynchus mykiss Walbaum) under in vitro incubation with extracts from leaves of various cultivars of Camellia japonica L. (Theaceae). Науково-технічний бюлетень Інституту тваринництва, Наи. акад. аграр. наук України. Харків, N 118, 2017. - C. 3-13. [The Scientific and Technical Bulletin of the Institute of Animal Science NAAS of Ukraine, National Academy of Agrarian Sciences of Ukraine, Kharkiv, N 118, 2017.]

15. Kharchenko, I., Maryniuk, M., Tkachenko, H., Buyun, L., PażontkaLipiński, P., Witaszek, M., Osadowski, Z. (2018). Superoxide dismutase activity level in the muscle tissue of the rainbow trout (Oncorhynchus mykiss Walbaum) as a biomarker of antioxidant properties of leaf extracts of Camellia japonica L. cultivars (Theасеае). Рыбохозяйственные водоёмы России: фундаментальные и прикладные исследования. Материалы II Всероссийской научной конференции с международным участием, ФГБНУ «Государственный научно-исследовательский институт озерного и речного рыбного хозяйства им. Л.С. Берга» (ФГБНУ «ГосНИОРХ»), Санкт-Петербург, 2-4 апреля 2018 г. [Fishery reservoirs of Russia: fundamental and applied research. Proceedings of the II All-Russian Scientific Conference with International Participation, FGBIU "L.S. Berg State Research Institute of the Lake 
and River Fisheries» (FGBNU «GosNIORH»), St. Petersburg, April 2-4, 2018.] P. 528-535.

16. Kharchenko, I., Maryniuk, M., Tkachenko, H., Buyun, L., PażontkaLipiński, P., Witaszek, M., Osadowski, Z. (2017)b. Total antioxidant activity of the muscle tissue of the rainbow trout (Oncorhynchus mykiss Walbaum) under incubation with extracts from leaves of various cultivars of Camellia japonica L. Scientific Journal of DALRYBVTUZ, 43(4): 18-26. (Харченко И. И., Маринюк М. М., Ткаченко Г. М., Буюн Л. И., Пажонтка-Липинский П., Виташек М., Осадовский 3. 2017. Общая антиоксидантная активность мышечной ткани радужной форели (Oncorhynchus mykiss Walbaum) в исследованиях in vitro с экстрактами из листьев различных сортов камелии японской (Camellia japonica L.). Научныле труды Дальрыбвтуза, 43(4), 18-26.)

17. Kunkel, G. (1984). Plants for human consumption. An annotated checklist of the edible phanerogams and ferns. Koenigstein: Koeltz Scientific Books, 393.

18. Landolt, M.L. (1989). The relationship between diet and the immune response. Aquaculture, 79: 193-206. DOI: 10.1016/0044-8486(89)90461-4.

19. Lee, H. H., Cho, J. Y., Moon, J. H., Park, K. H. 2011. Isolation and identification of antioxidative phenolic acids and flavonoid glycosides from Camellia japonica flowers. Hortic. Environ. Biotechnol., 52(3): 270-277. DOI: 10.1007/s13580-0110157-x.

20. Lee, J. H., Kim, J. W., Ko, N. Y., Mun, S. H., Kim, D. K., Kim, J. D., Kim, H. S., Lee, K. R., Kim, Y. K., Radinger, M., Her, E., Choi, W.S. (2008). Camellia japonica suppresses immunoglobulin E-mediated allergic response by the inhibition of Syk kinase activation in mast cells. Clin. Exp. Allergy, 38(5), 794-804. DOI: $10.1111 / \mathrm{j} .1365-2222.2008 .02936 . x$.

21. Levine, R. L. (2002). Carbonyl modified proteins in cellular regulation, aging, and disease. Free Radic. Biol. Med., 32(9), 790-796. DOI: 10.1016/s08915849(02)00765-7.

22. Levine, R. L., Garland, D., Oliver, C. N., Amic, A., Climent, I., Lenz, A. G., Ahn, B. W., Shaltiel, S., Stadtman, E. R. (1990). Determination of carbonyl content in oxidatively modified proteins. Methods in Enzymology, 186, 464-478. DOI: 10.1016/0076-6879(90)86141-h.

23. Long, M., Lin, W., Hou, J., Guo, H., Li, L., Li, D., Tang, R., Yang, F. 2017. Dietary supplementation with selenium yeast and tea polyphenols improve growth performance and nitrite tolerance of Wuchang bream (Megalobrama amblycephala). Fish Shellfish Immunol., 68, 74-83. DOI: 10.1016/j.fsi.2017.07.017.

24. Martínez, A., Portero-Otin, M., Pamplona, R., Ferrer, I. (2010). Protein targets of oxidative damage in human neurodegenerative diseases with abnormal protein aggregates. Brain Pathology, 20(2), 281-297. DOI: 10.1111/j.1750-3639.2009.00326.x.

25. Mizutani, T., Masaki, H. (2014). Anti-photoaging capability of antioxidant extract from Camellia japonica leaf. Exp. Dermatol., Suppl. 1, 23-26. DOI: $10.1111 /$ exd.12395.

26. Nakamura, S., Fujimoto, K., Nakashima, S., Matsumoto, T., Miura, T., Uno, K., Matsuda, H., Yoshikawa, M. (2012). Medicinal flowers. XXXVI. Acylated oleanane-type triterpene saponins with inhibitory effects on melanogenesis from the flower buds of Chinese Camellia japonica. Chem. Pharm. Bull., 60(6), 752758. DOI: $10.1248 / \mathrm{cpb} .60 .752$.

27. Nootash, S., Sheikhzadeh, N., Baradaran, B., Oushani, A. K., Maleki Moghadam, M. R., Nofouzi, K., Monfaredan, A., Aghebati, L., Zare, F., Shabanzadeh, S. (2013). Green tea (Camellia sinensis) administration induces expression of im- 
mune relevant genes and biochemical parameters in rainbow trout (Oncorhynchus mykiss). Fish Shellfish Immunol., 35(6), 1916-1923. DOI: 10.1016/j.fsi.2013.09.030.

28. Oh, G. S., Kang, S. S., Chung, M. G. (1996). Temporal genetic structure in Camellia japonica (Theaceae). Genes Genet. Syst., 71, 9-13. DOI: 10.1266/ggs.71.9.

29. Onodera, K., Tsuha, K., Yasumoto-Hirose, M., Tsuha, K., Hanashiro, K., Naoki, H., Yasumoto, T. (2010). Okicamelliaside, an extraordinarily potent antidegranulation glucoside isolated from leaves of Camellia japonica. Biosci. Biotechnol. Biochem., 74(12), 2532-2534. DOI: 10.1271/bbb.100630.

30. Salinero, C., Feás, X., Mansilla, J. P., Seijas, J. A., Vázquez-Tato, M. P., Vela, P., Sainz, M. J. (2012). ${ }^{1} \mathrm{H}$-nuclear magnetic resonance analysis of the triacylglyceride composition of cold-pressed oil from Camellia japonica. Molecules, 17(6), 6716-6727. DOI: 10.3390/molecules17066716.

31. Sayed, A.E.H., Soliman, H.A.M. (2018). Modulatory effects of green tea extract against the hepatotoxic effects of 4-nonylphenol in catfish (Clarias gariepinus). Ecotoxicol. Environ. Saf., 149, 159-165. DOI: 10.1016/j.ecoenv.2017.11.007.

32. Sheikhzadeh, N., Nofouzi, K., Delazar, A., Oushani, A. K. (2011). Immunomodulatory effects of decaffeinated green tea (Camellia sinensis) on the immune system of rainbow trout (Oncorhynchus mykiss). Fish Shellfish Immunol., 31(6): 12681269. DOI: 10.1016/j.fsi.2011.09.010.

33. Sousa, C., Quintelas, C., Augusto, C., Ferreira, E.C., Páscoa, R. N. M. J. (2019). Discrimination of Camellia japonica cultivars and chemometric models: An interlaboratory study. Computers and Electronics in Agriculture, 159, 28-33. DOI: 10.1016/j.compag.2019.02.025.

34. Stadtman, E. R., Levine, R. L. (2000). Protein oxidation. Ann. N Y Acad. Sci., 899, 191-208. DOI: 10.1111/j.1749-6632.2001.tb05632.x.

35. Stuart, R. G. A. (1979). Chinese Materia Medica: vegetable kingdom. Southern Materials Centre Inc., Taipei.

36. Tang, G. Y., Zhao, C. N., Xu, X. Y., Gan, R. Y., Cao, S. Y., Liu, Q., Shang, A., Mao, Q. Q., Li, H. B. (2019). Phytochemical Composition and Antioxidant Capacity of 30 Chinese Teas. Antioxidants (Basel), 8(6). DOI: 10.3390/antiox8060180.

37. Thawonsuwan, J., Kiron, V., Satoh, S., Panigrahi, A., Verlhac, V. (2010). Epigallocatechin-3-gallate (EGCG) affects the antioxidant and immune defense of the rainbow trout, Oncorhynchus mykiss. Fish Physiol. Biochem., 36(3), 687-697. DOI: $10.1007 / \mathrm{s} 10695-009-9344-4$.

38. Usher, G. (1974). A dictionary of plants used by man. London: Constable, $619 \mathrm{p}$.

39. Vela, P., Salinero, C., Sainz, M. J. 2013. Phenological growth stages of $\mathrm{Ca}$ mellia japonica. Ann. Appl. Biol., 162, 82-190. DOI: 10.1111/aab.12010.

40. Wang, C.-C., Ho, C.-T., Lee, S.-C., Way, T.-D. (2016). Isolation of eugenyl b-primeveroside from Camellia sasanqua and its anticancer activity in PC3 prostate cancer cells. J. Food Drug Analysis, 24, 105-111. DOI: 10.1016/j.jfda.2015.06.005.

41. Yoshikawa, M., Morikawa, T., Asao, Y., Fujiwara, E., Nakamura, S., Matsuda, H. (2007). Medicinal flowers. XV. The structures of noroleanane- and oleanane-type triterpene oligoglycosides with gastroprotective and platelet aggregation activities from flower buds of Camellia japonica. Chem. Pharm. Bull., 55(4), 606-612. DOI: $10.1248 / \mathrm{cpb} .55 .606$.

42. Zar, J. H. (1999). Biostatistical Analysis, $4^{\text {th }}$ ed. Prentice Hall Inc., New Jersey, $663 \mathrm{p}$.

43. Zhao, C. N., Tang, G. Y., Cao, S. Y., Xu, X. Y., Gan, R. Y., Liu, Q., Mao, Q. Q., Shang, A., Li, H. B. (2019). Phenolic Profiles and Antioxidant Activities 
of 30 Tea Infusions from Green, Black, Oolong, White, Yellow and Dark Teas. Antioxidants (Basel), 8(7). DOI: 10.3390/antiox8070215.

УРОВЕНЬ ОКИСЛИТЕЛЬНО-МОДИФИЦИРОВАННЫХ БЕЛКОВ МЫШЕЧНОЙ ТКАНИ РАДУЖНОЙ ФОРЕЛИ (ONCORHYNCHUS MYKISS WALBAUM) КАК БИОМАРКЕР АНТИОКСИДАНТНЫХ СВОЙСТВ ЭКСТРАКТОВ ЛИСТЬЕВ РАЗНЫХ СОРТОВ CAMELLIA JAPONICA L. (THEACEAE D. DON)

Буюн Л., Харченко И., Маринюк М., Национальный ботанический сад имени Н. Н. Гришко, Национальная академия наук Украины, Киев, Украина

Ткаченко Г., Осадовский 3., Институт биологии и охраны среды Поморской академии в Слупске (Слупск, Польша)

Изучено антиоксидантную активность растительных экстрактов Саmellia japonica L. путем определения содержания альдегидных и кетоновых производных окислительно-модифицированных белков. Было установлено, что экстракты листьев Camellia japonica L. 'Kramer's Supreme', C. japonica 'C.M. Wilson', C. japonica 'La Pace', C. japonica 'Benikarako', C. japonica 'Fanny Bolis' оказывают протекторный эффект на окислительное повреждение белков в мышечной ткани радужной форели. Листья различных сортов Caтеllia јаропіса, культивируемых в условиях оранжерейной культуры, были собраны в Начиональном ботаническом саду имени Н. Н. Гришко (НБС) Начиональной академии наук Украиньл. Свежие листья промывали, взвешивали, измельчали и гомогенизировали в 100 мМ фосфатном буфере $($ рH 7,2) (в соотночении 1:19, в/о) при комнатной температуре. После этого отфильтрованные экстракты подвергали исследованию. В исследованиях были использованы особи радужной форели со средней массой тела 80-120 г. Образиы тканей промывали и гомогенизировали в ледяном буфере (100 мМ Tрис-HCl, pH 7,2) при помощи стеклянного гомогенизатора, погруженного в ледяную баню. Полученные 10 \%-ные гомогенаты центрифугировали при $3000 \mathrm{~g}$ в течение 15 мин при $4{ }^{\circ} \mathrm{C}$. После центрифугирования супернатант мышечной ткани рыб использовали для инкубации с экстрактами листьев различных сортов С. jаропіса (в соотношении 19:1) при комнатной температуре.

Контрольную группу (мышечную ткань форели) инкубировали с 100 мМ Tрис-HCl буфером (рН 7,2) (в соотношении 19:1). Продолжительность инкубации составляла 2 часа. При инкубаџии мышечной ткани с экстрактами листьев разных сортов С. јаропіса, уровень альдегидных производных был сопоставлен со значением этого показателя для контрольной группы. Среди шести исследованных экстрактов, наивысший ингибирующий эффект был характерен для C. jаропіса 'La Pace' (снижение уровня кетоновых производных составило 28,2 \% $(p<0,05)$ по сравнению с контрольной группой). Уровень кетоновых производных окислительно-модифищированных белков в образие с экстрактом C. jаропіса 'Mrs. Lyman Clarke' возрос на 2,8 \% (p>0,05) по сравнению с контрольными значениями. Наиболее низкий уровень кетоновых производных характерен для экстракта листьев C. јаропіса 'La Pace'. Следовательно, экстракты листьев Camellia jаропіса могут быть использовань в аквакультуре в качестве антиоксидантного средства, принимая во внимание его доступность и низкую себестоимость. Более того, использование таких растительных продуктов в качестве антиоксидантов и иммуностимуляторов в аквакультуре может также оказывать положительное влияние на окружающую среду ввиду их биоразлагаемости.

Ключевые слова: радужная форель (Oncorhynchus mykiss Walbaum), мышечная ткань, Camellia jaропіса L., сорта, окислительно-модифицированные белки. 
РІВЕНЬ ОКИСНЮВАЛЬНО-МОДИФІКОВАНИХ БІЛКІВ У М'ЯЗОВІЙ ТКАНИНІ РАЙДУЖНӦ̈ ФОРЕЛI (ONCORHYNCHUS MYKISS WALBAUM) ЯК БІОМАРКЕР АНТИОКСИДАНТНИХ ВЛАСТИВОСТЕЙ ЕКСТРАКТІВ ЛИСТКІВ PIЗHИХ СОРТIB CAMELLIA JAPONICA L. (THEACEAE D. DON)

Буюн Л., Харченко І., Маринюк М., Начіональний ботанічний сад імені М. М. Гришка, Національна академія наук України, Київ, Україна

Ткаченко Г., Осадовський 3., Інститут біології та охорони середовища Поморської академії в Слупську (Слупськ, Польща)

Досліджено антиоксидантну активність рослинних екстрактів Camellia japonica L. шляхом визначення вмісту альдегідних та кетонових похідних окиснювально-модифікованих білків. Було встановлено, щзо екстракти листків Camellia japonica L. 'Kramer's Supreme', C. japonica 'C.M. Wilson', C. japonica 'La Pace', C. japonica 'Benikarako', C. japonica 'Fanny Bolis' виявляють протекторний ефект на окиснювальне пошкодження білків у м'язовій тканині райдужної форелі. Листки різних сортів Camellia јаропіса, щзо культивуються за умов оранжерейної культури, були відібрані в Наџіональному ботанічному саду імені М. М. Гришка (НБС) Національної академії наук України. Свіжозібрані листки промивали, зважували, подрібнювали та гомогенізували у 100 мМ фосфатному буфері (рН 7,2) (співвідношення 1:19, в/о) при кімнатній температурі. Після иьього було досліджено відфільтровані екстракти. У дослідженнях було використано особини райдужної форелі, середня маса яких складала 80-120 г. Зразки тканин промивали та гомогенізували у льодяному буфері (100 мM Tpic- $\mathrm{HCl}, \mathrm{pH} \mathrm{7,2)} \mathrm{за} \mathrm{до-}$ помогою скляного гомогенізатора, зануреного у льодяну баню. Отримані 10 \%-ні гомогенати центрифугували при $3000 \mathrm{~g}$ упродовж 15 хв при $4{ }^{\circ} \mathrm{C}$. Після центрифугування супернатант м'язової тканини риб було використано для інкубачї̈ з екстрактами листків різних сортів С. јаропіса (у співвідношенні 19:1) при комнатній температурі.

Контрольну групу (м'язову тканину форелі) інкубували з $100 \mathrm{mM} \mathrm{Tpic-HCl}$ буфером (рН 7,2) (у співвідношенні 19:1). Тривалість інкубаиії складала 2 години. При інкубації м'язової тканини з екстрактами листків різних сортів C. јаропіса, рівень альдегідних похідних було співвіднесено зі значенням ирього показника для контрольної групи. Як виявилось, серед шести досліджених екстрактів, найвищий інгібуючий ефект був характерний для C. јаропіса 'La Pace' (зниження рівня кетонових похідних склало 28,2 \% ( $<<0,05)$ у порівнянні з контрольною групою). Натомість, рівень кетонових похідних окиснювально-модифікованих білків у зразку з екстрактом C. japonica 'Mrs. Lyman Clarke' niдвищився на 2,8 \% (p>0,05) y порівнянні з контрольними значеннями. Найнижчий рівень кетонових похідних характерний для екстракту листків C. јаропіса 'La Pace'. Bідповідно, екстракти листків Camellia jаропіса можуть бути використані в аквакультурі як антиоксидантні засоби, беручи до уваги їх доступність та низьку собівартість. Тим більше, використання таких рослинних продуктів як антиоксиданти та імуностимулятори в аквакультурі може виявляти позитивний вплив на оточуюче середовище у зв'язку з їх здатністю до біологічного розпаду.

Ключові слова: райдужна форель (Oncorhynchus mykiss Walbaum), м'язова тканина, Camellia јаропіса L., сорти, окиснювально-модифіковані білки. 